\title{
Media Influence: Cognitive and Psychological Markers (On Chinese Medical and Cosmetic Advertising Texts)
}

\section{Influencia de los medios: marcadores cognitivos y psicológicos (en textos publicitarios médicos y cosméticos chinos)}

\author{
Olga D. Shmeleva \\ Institute of Foreign Languages, Volgograd State Socio-Pedagogical University, Volgograd, \\ Russia \\ ORCID: https://orcid.org/0000-0001-7869-2834 \\ Marina R. Zheltukhina* \\ Institute of Foreign Languages, Volgograd State Socio-Pedagogical University, Volgograd, \\ Russia. \\ ORCID: https://orcid.org/0000-0001-7680-4003 \\ Gennady G. Slyshkin \\ Law Institute, Russian University of Transport, Moscow, Russia. \\ ORCID: https://orcid.org/0000-0001-8121-0250 \\ Olga P. Ryabko \\ Institute of Philology, Journalism and Intercultural Communications, Southern Federal \\ University, Rostov-on-Don, Russia. \\ ORCID: https://orcid.org/0000-0003-4699-6395

\section{Galina N. Ostrikova} \\ Socio-Humanitarian Faculty, Don State Technical University, Rostov-on-Don, Russia. \\ ORCID: https://orcid.org/0000-0001-6348-029X

\section{Larisa V. Ukhova} \\ Faculty of Russian Philology and Culture, Yaroslavl State Pedagogical University named after \\ K.D. Ushinsky, Yaroslavl, Russia. \\ ORCID: https://orcid.org/0000-0001-6502-2540 \\ Zhanna K. Gaponova \\ Faculty of Russian Philology and Culture, Yaroslavl State Pedagogical University named after \\ K.D. Ushinsky, Yaroslavl, Russia. \\ ORCID: https://orcid.org/0000-0003-1615-3709
}

Received 01-12-20 Revised 01-25-20 Accepted 04-13-20 On line 06-29-20

*Correspondence

Email: zzmr@mail.ru
Cite as:

Shmeleva, O.D., Zheltukhina, M.R., Slyshkin, G.G., Ryabko, G.P., Ostrikova, G.N., Ukhova, L.V., \& Gaponova, Z.Q. (2020). Media Influence: Cognitive and Psychological Markers (On Chinese Medical and Cosmetic Advertising Texts). Propósitos y Representaciones, 8 (SPE2), e798. Doi: http://dx.doi.org/10.20511/pyr2020.v8nSPE2.798 


\section{Summary}

The main extralinguistic markers of influence in the Chinese medical and cosmetic advertising media discourse are nonverbal, linguocultural conceptual, cultural and historical, cognitive and psychological markers. The article is devoted to a research of cognitive and psychological markers of influence. In the article the most frequency cognitive and psychological markers of influence in the Chinese medical and cosmetic media advertising become known: the built-in messages (unusual decision, motivation to activity, conversations with others and stories about others). The fact that such markers as metaphorical communication and expansion of mass media images, consciousness fragmentation are more significant for the Chinese linguistic culture is established. The research clearly demonstrates that such markers of influence as choice illusion, destruction of time feeling and activization of submodalities are less common in the Chinese medical and cosmetic media advertising. The article contributes to the development of discursive linguistics, psycholinguistics, sociolinguistics, cultural linguistics, discourse theory and influence theory, media linguistics on the example of advertising media, lexicology and Chinese language stylistics.

Keywords: markers of influence, extralinguistic markers of influence, cognitive and psychological markers, medical and cosmetic media advertising, media discourse, China.

\section{Resumen}

Los principales marcadores extralingüísticos de influencia en el discurso mediático publicitario médico y cosmético chino son los marcadores no verbales, lingüísticos, conceptuales, culturales e históricos, cognitivos y psicológicos. El artículo está dedicado a la investigación de marcadores de influencia cognitivos y psicológicos. En el artículo se dan a conocer los marcadores cognitivos y psicológicos de influencia más frecuentes en la publicidad mediática médica y cosmética china: los mensajes incorporados (decisión inusual, motivación para la actividad, conversaciones con otros e historias sobre otros). Se establece el hecho de que marcadores como la comunicación metafórica y la expansión de las imágenes de los medios de comunicación, la fragmentación de la conciencia son más significativos para la cultura lingüística china. La investigación demuestra claramente que marcadores de influencia como la ilusión de elección, la destrucción del sentimiento del tiempo y la activación de submodalidades son menos comunes en la publicidad de los medios médicos y cosméticos chinos. El artículo contribuye al desarrollo de la lingüística discursiva, la psicolingüística, la sociolingüística, la lingüística cultural, la teoría del discurso y la teoría de la influencia, la lingüística de los medios sobre el ejemplo de los medios publicitarios, la lexicología y la estilística del idioma chino.

Palabras clave: marcadores de influencia, marcadores de influencia extralingüísticos, marcadores cognitivos y psicológicos, publicidad mediática y cosmética en medios, discurso mediático, China.

\section{Introduction}

The relevance of the study is due to the increased attention of scientists to the interpretation of Chinese linguoculture (Makarova et al., 2019). The rich centuries-old culture of this country has affected the life of modern society. Citizens of China take the beauty and health of the nation seriously, so the study of Chinese medical and cosmetic media advertising is of undeniable scientific and applied interest. In addition, the number of works devoted to this topic from a linguistic point of view is small. This topic is of interest to specialists in related fields: linguists, psychologists, sociologists, cultural scientists, advertising and PR specialists (Faleeva et al., 2017; Kvon et al., 2017). Modern works in the field of language theory, discursive linguistics make it necessary to rethink and generalize both theoretical and actual material accumulated by linguists 
in the sphere of study of various types of discourse, including advertising media. There is a stable research interest in the development of effective means and methods of transmitting rational and emotional information, speech influence. Modern media advertising directly contributes to the development of the medical and cosmetic industry, as many people choose precisely in favor of an advertised medicine or cosmetic product. An interdisciplinary approach at the intersection of language theory, discursive and applied linguistics, pragmalinguistics, cultural studies, psychology, journalism, media linguistics and internet linguistics to the study of advertising in modern Chinese media research provides a basis for new research to reveal the features of Chinese medical and cosmetic media advertising exposure.

The object of the study is Chinese medical and cosmetic media advertising. As a subject are specific extralinguistic markers of exposure of advertising media, which cause complex thinking and description of cognitive and psychological influence of Chinese medical and cosmetic advertising in media advertising in the XXI century. Scientific novelty of work consists in identification of cognitive and psychological markers as extralinguistic markers of exposure in Chinese medical and cosmetic advertising in modern media advertising discourse.

The theoretical significance lies in the identification of key cognitive and psychological markers of the influence of Chinese medical and cosmetic media advertising on the addressee. The study contributes to the development of discursive linguistics, psycholinguistics, sociolinguistics, cultural linguistics, discourse theory and influence theory, media linguistics on the example of advertising media, lexicology and Chinese language stylistics. The algorithm of analysis of advertising media activity in the field of medicine and cosmetology in Chinese linguoculture, proposed in the article, can be used for research of media advertising in other spheres of human life activity in different linguocultures.

The practical value of the study is the possibility of applying the results of work and selected material in university practical classes in Chinese language, in theoretical courses in linguistics, lexicology, grammar, stylistics, discourse theory, influence theory, as well as in the process of linguistic analysis of advertising media texts in Chinese.

\section{Literature Review}

Interest in media communication prevails in modern society. Mass media not only have a huge influence on the public consciousness, but also manipulate it in the interests of the addressee (Orekhovskaya et al., 2019). One of the dominant areas of influence is advertising media.

Advertising discourse is central to the research of many linguists within the study of the language of advertising and speech influence, in the field of mass communication and intercultural communication, in the field of rhetoric and stylistics (Jamieson \& Campbell, 1997; Zheltukhina, 2003; Kaftandzhiyev, 2005, etc.). The object of the advertising discourse is advertising, which is currently of interest not only to sociologists, political scientists, marketers, psychologists, cultural scientists, but also to linguists, as it gives the possibility to reveal its linguistic aspects. Research of functional, semantic and genre characteristics of advertising in terms of stylistics and discourse analysis, peculiarities of construction of advertising text and its semantic and pragmatic organization, use of verbal and non-verbal signs, advertising name, etc. (Dijk van, 1988; Dijk van, 1997; Kara-Murza, 1996; Kryukova, 2004; Kaftandzhiyev, 2005; Vartanova, 2006; Kirpicheva, 2007; Ukhova \& Marycheva, 2012; Kalashaova, 2014; Naumova \& Budnik, 2014; Aniskina \& Ukhova, 2015; Busygina \& Zheltukhina, 2015; Boeva-Omelechko et al., 2019; Tameryan et al., 2018a; 2018b; 2019b; Zhang et al., 2019; Zheltukhina et al., 2019, etc.). It is important to emphasize the fact that previously scientists have not analyzed Chinese medical and cosmetic media advertising in the cognitive and psychological aspect of the media effect on the recipient (Shmeleva, 2018; Volskaya et al., 2018). 
The hypothesis of the study is that Chinese medical and cosmetic media advertising has a direct effect, revealed in extralinguistic markers, including cognitive and psychological markers, not only on the recipient as a consumer of advertising products and advertising services, but also on Chinese linguoculture, which in turn affects the creation of medical and cosmetic advertising media.

The aim of the study is to identify cognitive and psychological exposure markers in Chinese medical and cosmetic media advertising.

\section{Methodology}

The methodological basis of the study is a systemic approach, including cognitive, pragmatic, linguocultural, social, psychological aspects, according to which any phenomenon is considered as integrity in the unity of all its connections and relations. According to the objective, the following research methods were used: inductive method, deductive method, linguocultural conceptual analysis, definition analysis, etymological analysis, lexical and semantic analysis, lexical and grammatical analysis, stylistic analysis, interpretation analysis, content analysis, reception of quantitative calculations.

The material of the study was selected by a continuous sampling method from Chinese medical and cosmetic advertising media sources of the XXI century. In the process of the study 1000 printed and video ads in Chinese were analyzed. The unit of analysis is the text of medical or cosmetic advertising in Chinese, presented in the media.

\section{Results and Discussion}

The study found that medical and cosmetic media advertising is an advertisement in mass media aimed at distributing and introducing medical and cosmetic goods and services directly related to the health and beauty of modern man as significant concepts with a dominant value component in different linguocultures, through various communication channels (print, radio, television and Internet) (Zheltukhina \& Shmeleva, 2017). Medical and cosmetic advertising performs informational and influencing functions in modern Chinese media market with dominance of the latter. Advertising media targeting of medical and cosmetic advertising media in Chinese is necessary for effective influence on the addressee and is represented by the following varieties: 1) inter-subject and 2) inter-discourse (Zheltukhina, 2003; Zheltukhina \& Shmeleva, 2017). This article is dedicated to the identification of the main cognitive and psychological exposure markers in Chinese medical and cosmetic media advertising.

It should be stressed that a person is subjected to hypnosis daily, falling into a familiar trance at the screen of a TV or computer. Typically, it is a hidden hypnosis that imperceptibly affects such part of the subconsciousness as the "collective unconsciousness". The media actively use the basic principles of hypnosis (Copelan, 2001; Roet, 2002; Vertyankina, 2005; Grimak, 2001; Zheltukhina, 2003): 1) relaxation; 2) concentration; 3) suggestion.

Information in advertising should be expressive and attractive subconsciously. By relaxing and focusing, the addressee absorbs all the information that is inspired. The principle of hypnosis is also used, such as repetition, which enhances the effect of suggestion by activating behavior at the level of nervous system reflexes, automatic reproducibility. Reflexes are stable reactions based on certain images. The human brain constantly analyzes many successive images of the past and present, sometimes the future. At the same time, it is necessary to be able to separate pleasant impressions from undesirable ones, as it depends on adequacy of reflex base formation. Every promotional video, every informational message has an invisible and purposeful influence on human health and behavior. 
Television and the Internet, radio and print media carry out mass inspiration in medical and cosmetic media advertising, put the mind to sleep and plunge it into a state of high inducibility, adjust the human brain to wait for pain in a healthy state, encouraging the purchase of sleeping pills, fat burns, tonic, sedative, painkillers. Daily media (television, radio, newspapers and magazines, Internet) allows the addressee to detect symptoms of all ailments and consult a doctor waiting for the worst news. After a thorough examination, the patient is not satisfied with the doctor's conclusion about his full health, as the media suggestiveness left a deep mark in his mind. Hypochondria and valetudinarianism are at the heart of many psychosocial disorders. Human thought can also be a signal triggering a certain sequence of actions. Among the increase in diseases, advertisers and the media, which replicate the means of treatment of various diseases, are partly responsible. The media in their advice help not only to heal from all diseases, but also to solve all difficult problems, creating such feelings at the addressee (Zheltukhina, 2003). To influence consciousness or subconsciousness in media advertising, the effect of awakening in the destination of physical desires, emotions: fear, guilt, feeling alone, etc. The suggestive mechanism of media advertising, affecting human consciousness, does not create new needs. Efficiency is evident in decision-making. This always compares anything presented to the consciousness and beyond.

The analysis of Chinese factual material revealed the main cognitive and psychological markers of exposure in Chinese medical and cosmetic media advertising.

\section{Built-in Messages (34.6\%)}

Parenthesis or sneaking are small fragments of large statements that attract the attention of the unconsciousness, thanks to changes in pose, intonation, pauses, graphical highlights, contextual synonyms, keyword repeats.

For example:

- the unusual decision (tracks with creation of comic effect):

Choose "Lebailin", health and joy will be your eternal companion!!

In this case, an unusual solution is the subconscious influence of the addressee in order for the addressee to decide to buy an advertised product with which his life will "simplify" and become "joyful".

- motivation to activity:

Lightning-fast enter the battle (which implies fighting overweight). mood.

In the given example, the inducement to activity is expressed by way of an imperative

- conversations with others and stories about others:

Which people are easy to get cerebrovascular disease? The following are situations when it is easy for a middle-aged and elderly person to get a cerebrovascular disease: hereditary history of the disease, overweight people, hypertension, diabetes, heart disease, smoking and drinking alcohol, with high blood pressure, emotional excitement.

The example offers an indirect dialogue (questions and answers), a story about third parties, possible health problems. The influence is emotional threatening, causing fear in people to acquire a certain disease or to find it in themselves or their relatives. 


\section{Metaphorical Communication (11.8\%)}

It is a good way to address the unconscious psyche, the right hemisphere of the recipient's brain. The metaphor carries a message in which an object is described or expressed in the language of another object. Adjustment to the metaphorical field of the destination is implemented.

For example:

Strike with a fist (illness).

"Thai boxing" consists of "fist" and- "beat (the enemy), to strike (enemy) blow". In this example, "strike" means "deal with disease."

\section{The Expansion of Mass Media Life Samples (11.8\%)}

This type leads to a rather well-known syndrome of "consumption madness", when all layers try to reach screen "virtual" standards (in Russia and other countries of the "third" and "fourth" world). People abandon old stereotypes, the ways and mechanisms of their existence in the past for the sake of what has been shown through virtual images, through the expansion of samples of the unattainable, "bright" present and future (Tameryan et al., 2019a). Here you can cite a huge amount of Chinese cosmetic advertising of creams that bleach the skin. As is known, modern Chinese women want to be similar to European women.

\section{Fragmentation of Consciousness (11.3\%)}

This fragmentation realizes through the phenomenon of the "clip" character of messages and images, as well as their meaning disjointed as a psychological association of urgency with importance (Schiller, 1980; Zheltukhina, 2003). Messages with the announcement "urgently," whatever they are about, are perceived by the viewer as super-powerful, turning in his mind a hierarchy of values into chaos. Plus: interruption of any stories (from acute political analysis to artistic film drama) is extremely contrasting with regard to the main context in meaning, style, audio / video order, volume with advertising inserts and clips always automatically includes the same psychological mechanisms of urgency, importance, creating in the head of the addressee a completely monstrous, structural "sense porridge". The flow of information, which is always perceived by our consciousness as fragments of a single text, accumulates sense errors in such a broadcast. Adjacent fragments of text, various components of text (speech, video, audio tracking, color and tempo-rhythm qualities of fragments) conflict in consciousness. In addition, a mistake often arises between the media text and the existential, life context. Thus, the flow of conflictshaped fragments represents a mosaic culture (Ortega y Gasset, 1990), the collapse of the unity of life, because it cannot fit in consciousness, much less build into something holistic (sense, worldview, motivational).

In Chinese medical and cosmetic media ads it is often possible to observe words such as action, discounts. The addressee will subconsciously respond to these inscriptions so as not to miss the moment to buy the medicine for a lower price.

For example,

Price drop discounts gold autumn, big promotion.

And near we can see a big bright hieroglyph, that means "economy".

\section{Illusion of Choice (10.5\%)}

This is a technique of influence on conscious sphere of psyche of the addressee with provision of freedom of choice. In offering a choice, the addressee is inspired to agree with the essence.

For example, 


\section{Just cure enteropathy (chronic bowel pathology), choose a life without diarrhea. \\ Capsules for the treatment of the intestine and stomach.}

In the media advertising, the addressee is veiled with information about the need to purchase the advertised medicine: having opted for another medicine, the addressee will have to fight his illness long and painfully. In this case, the addressee is offered a non-existent alternative that creates the illusion of selection and decision-making.

\section{Destruction of Time Sensation (10.4\%)}

At the same time as the "disintegration of the unity of life" in consciousness, what is called the "disintegration of the sense of time" takes place. Mass media creates in the mind of the addressee a virtual "performance time", which, first, is broken and may not correlate at all with real time and, second, is characterized by "amputation of meaning". The emergence of the phenomenon of "torn," clip "mass consciousness is related to the expansion of "humanitarian technologies" in the media discourse (Zheltukhina, 2003). In this regard, all the information and cultural text that the media offers to its target consumers is the "Big Show" of self-sufficient images, which does not need to be united with the (allegedly absent) reality of events, space and time. Because the postmodern trend in mass media denies the need to follow reality, the role of these very media in influencing reality, in the management of society through images does not disappear or decrease.

Activation of submodalities (Alder, 2001) or nonverbal patterns (Labunskaya \& Nogerova, 1997, pp. 478-486) (9.6\%)

Texts saturated with tropes (metaphors, metonyms, impersonations) affecting all submodalities are used to achieve maximum influence. In the Chinese medical and cosmetic media advertising the following types of submodalities meet (Zheltukhina, 2003):

1) visual: brightness, contrast, size, clearness, chromaticity / black-and-white image, limitation size / panorama, saturation, focus, shades or color balance, movement, form, prospect, arrangement, distance;

2) sound (acoustic): pitch height, duration of sound, tempo (speed of speech), localization, volume, distance, timbre or tone, source, quantity, mono / stereo, continuity / discontinuity of sound, pauses, clarity;

3) kinesthetic: pressure, motion, location, duration, number, intensity, texture, shape, temperature, frequency (tempo);

4) gustatory: taste;

5) olfactory: odors.

For example:

Skin breathes.

In the example of Chinese media advertising, human skin is impersonated.

The role of submodalities in the advertising media process is that they are involved in the creation of the reality maps used by the addresser and the addressee. People mostly operate on visual images, then go sound, and after them - kinesthetic images. Olfactory and taste images, although they may play an essential role in particular memories, are not frequent in everyday life and are not significant in the language of the media. As a result of analysis of TV and radio programs, the press traces sensory preferences in Chinese media advertising due to the frequency 
of use of certain phrases and turns, predicates, keywords - verbal sensory keys, most typical for certain modality.

The use of quantitative counting has yielded the following results. It has been found that the frequency of fixation of markers of medical and cosmetic advertising media activity in Chinese media examination is distributed in the following descending sequence: built-in messages (34.6\%), metaphorical communication and expansion of mass media life samples (11.8\% each), fragmentation of consciousness (11.3\%), illusion of choice (10.5\%), destruction of time sensation $(10.4 \%)$ and activation of submodalities (9.6\%).

\section{Conclusion}

According to the study, cognitive and psychological features of the influence on the addressee are actively implemented by the media addressee in Chinese medical and cosmetic media advertising. Modern media advertising can influence all spheres of human activity in certain interests of the media addressee.

As a result of the analysis of the actual material, it was found that the most frequency markers of cognitive and psychological influence in Chinese medical and cosmetic media advertising are built-in messages (34.6\%). These include: unusual decision, motivation to activity, conversations with others and stories about others. It is noteworthy that for Chinese linguoculture such cognitive and psychological markers of influence in medical and cosmetic media advertising as built-in messages (34.6\%), metaphorical communication and expansion of mass media life samples $(11.8 \%$ each), fragmentation of consciousness $(11.3 \%)$ are more significant. Less frequent in Chinese media advertising of medical and cosmetic goods and services are exposure markers such as illusion of choice $(10.5 \%)$, destruction of time sensation $(10.4 \%)$ and activation of submodalities $(9.6 \%)$.

It is established that mass media in medical and cosmetic advertising communication are filters that, due to the lack of direct perception by the addressee of the surrounding reality, as a result of the selection of information and the formulation of messages, opinions, assessments, are able to create distorted, shifted images of reality, having a strong influence on the addressee in order to achieve the objectives of the addressee.

\section{Acknowledgement}

The publication was carried out as a part of the program of supporting the publication activity of the Southern Federal University.

The publication has been prepared with the support of the Yaroslavl State Pedagogical University named after K.D. Ushinsky.

\section{References}

Alder, G. (2001). NLP: Modern Psychotechnologies. Saint Petersburg: AST.

Aniskina, N.V. \& Ukhova, L.V. (2015). The Axiological world view of a modern advertising consumer. Annales. Series Historia Naturalis, 25(3), 477-484.

Boeva-Omelechko, N.B., Posternyak, K.P., Zheltukhina, M.R., Ponomarenko, E.B., Talybina, E.V., Kalliopin, A.K. \& Ovsyannikova, M.N. (2019). Two Images of Russia in the British Political Mass Media Discourse of 1991 - 1993 and 2013 - 2019: Pragmastylistic Aspect. Online Journal of Communication and Media Technologies, 9(4), e201926. URL: https://doi.org/10.29333/ojcmt/5952 
Busygina, M.V. \& Zheltukhina, M.R. (2015). Correlation of the Concepts "Press Release", "News", "Advertising" in the Modern Media Discourse. Cognitive Researches of Language, 20, 641-653.

Copelan, R. (2001). Hypnosis: Practical Management. Saint Petersburg: Piter.

Dijk van, T.A. (1988). News as Discourse. New Jersey: Lawrence Elbbaum Assoc. Publ.

Dijk van, T.A. (1997). Discourse as Structure and Process: Discourse Studies a Multidisciplinary Introduction. Thousand Oaks: SAGE Publication Ltd.

Faleeva, L.V., Bratukhina, E.V., Ezhov, S.G., Gorbunova, L.N., Lopanova, A.P., Viaznikova, L.F. \& Kryukova, N.I. (2017). Student's social experience forming in university vocational training. Eurasian Journal of Analytical Chemistry, 12(7), 1127-1135.

Grimak, L.P. (2001). Advertising Hypnosis: Anatomy of Mental Aggression Ideal Form. Advertising: Suggestion and Manipulation. The Media Focused Approach. Samara, 1, 727-742.

Jamieson, K.H. \& Campbell, K.K. (1997). The Interplay of Influence: News, Advertising, Politics and Mass Media. Belmont: Wadsworth Publishing Company.

Kaftandzhiyev, X. (2005). Harmony in Advertising Communication. Moscow: Exmo.

Kalashaova, A.A. (2014). Linguopragmatic Features of Advertising in the Higher Education Sphere. AGU Bulletin, 3(145), 30-34.

Kara-Murza, E.S. (1996). The Culture of the Russian Speech in Advertising Activity. Journalism and Culture of the Russian Speech, 4, 63-74.

Kirpicheva, O.V. (2007). Onomasticon of the Advertising Text: PhD thesis. Volgograd: VSSPU.

Kryukova, I.V. (2004). Advertising Name: from Invention to Precedence: DrSc. thesis. Volgograd: VSSPU.

Kvon, G.M., Faleeva, L.V., Pyrkova, G.K., Alyakina, D.P., Mustafina, A.A., Kryukova, N.I. \& Blekus, V.V. (2017). Strategic Priorities of Regional Investment Activity. Eurasian Journal of Analytical Chemistry, 12(7B), 1099-1106.

Labunskaya, V.A. \& Nogerova, M.T. (1997). Nonverbal Patterns of Role Behavior. Psychological Bulletin, 2(1), 478-486.

Makarova, E.V., Kryukova, N.I., Sizova, Z.M., Grinenko, A.V., Erofeeva, M.A. \& Bukalerova, L.A. (2019). Divergence of Supreme Values of Russian World and Western Civilization Social and Philosophical Analysis. European Journal of Science and Theology, 15(3), 97107.

Naumova, D.D. \& Budnik, E.A. (2014). Verbal and Nonverbal Means of Drawing Attention in Advertising Communication. Bulletin of VSU. Linguistics and Cross-cultural Communication, 4, 36-39.

Orekhovskaya, N.A., Chistyakov, A.A., Kryukova, N.I., Krokhina, J.A., Ospennikov, Y.V. \& Makarova, E.V. (2019). Orthodoxy and modernity their contact facets in Russian society. European Journal of Science and Theology, 15(2), 67-77.

Ortega y Gasset, J. (1990). Two Great Metaphors. Moscow: Progress.

Roet, B. (2002). Understanding Hypnosis. Moscow: EKSMO-Press.

Schiller, G. (1980). Manipulators of consciousness. Moscow: Mysl'.

Shmeleva, O.D. (2018). Influence Specifics of Medical and Cosmetic Advertising in the Modern Chinese and Russian Media Discourse: PhD thesis. Moscow: MCU.

Tameryan, T.Y., Zheltukhina, M.R., Slyshkin, G.G., Zelenskaya, L.L., Ryabko, O.P. \& Bodony, M.A. (2019b). Political Media Communication: Bilingual Strategies in the Pre-Election Campaign Speeches. Online Journal of Communication and Media Technologies, 9(4), e201921. URL: https://doi.org/10.29333/ojcmt/5869

Tameryan, T.Yu., Zheltukhina, M.R., Sidorova, I.G. \& Shishkina, E.V. (2019a). Stereotype Component in the Structure of Ethnocultural Archetype (On Internet-Blogs). The European Proceedings of Social \& Behavioural Sciences, 200, 1716-1722. URL: https://dx.doi.org/10.15405/epsbs.2019.03.02.200 
Tameryan, T.Yu., Zheltukhina, M.R., Slyshkin, G.G., Abakumova, O.B., Volskaya, N.N. \& Nikolaeva, A.V. (2018a). Metaphor in Political Media Discourse: Mental Political Leader Portrait. Online Journal of Communication and Media Technologies, 8(4), 377-384.

Tameryan, T.Yu., Zheltukhina, M.R., Slyshkin, G.G., Shevchenko, A.V., Katermina, V.V. \& Sausheva, Ye.V. (2018b). New Country's Political Discourse: Formation of Speech Technologies. Modern Journal of Language Teaching Methods, 8(7), 151-160.

Ukhova, L.V. \& Marycheva, D.N. (2012). Advertising Names as Communication Means with the Consumer. Yaroslavl Pedagogical Bulletin, 1(3), 119-123.

Vartanova, N.G. (2006). Structural-Semantic and Functional Features of the Advertising Interview Genre in the Russian and French Media: DrSc. thesis. Rostov-on-Don: RSPU.

Vertyankina, N.V. (2005). Suggestive Parameters of the Pragmonimical Advertising Discourse in the Modern Mass Media: PhD thesis. Krasnodar: TSU.

Volskaya, N.N., Tameryan, T.Yu., Zheltukhina, M.R., Boeva-Omelechko, N.B., Komleva, L.A. \& Knyazeva, Ye.G. (2018). Literary Translation as Cognitive Overlap between Foreign and Native Languages. Modern Journal of Language Teaching Methods, 8(7), 161-172.

Zhang, K., Denisenko, V.N., Ponomarenko, E.B., Zheltukhina, M.R., Denisenko, A.V. \& Shiryaeva, O.V. (2019). The Newest Borrowed Words and Methods of their Formation in the Russian- and Chinese-Language Internet Communication Space. Online Journal of Communication and Media Technologies, 9(4), e201924. URL: https://doi.org/10.29333/ojcmt/5930

Zheltukhina, M.R., Bondareva, N.V., Zelenskaya, L.L., Anikeeva, I.G., Malygina, L.E. \& Chistyakov, A.V. (2019). Media Promotion Role of Economic Vocabulary: Specific Features and Functions in Presentation and Advertisement. Online Journal of Communication and Media Technologies, 9(2), e201907. URL: https://doi.org/10.29333/ojcmt/5733

Zheltukhina, M.R. \& Shmeleva O.D. (2017). Main Verbal Characteristics of the Chinese and Russian Medical and Cosmetic Media Advertising: Linguocultural Specifics. Ivzestia of the Volgograd State Pedagogical University, 4(117), 136-140.

Zheltukhina, M.R. (2003). Tropological Suggestiveness of the Mass Media Discourse: about a Problem of Tropes Speech Influence in the Media Language. Volgograd: Izd-vo VF MUPK. 